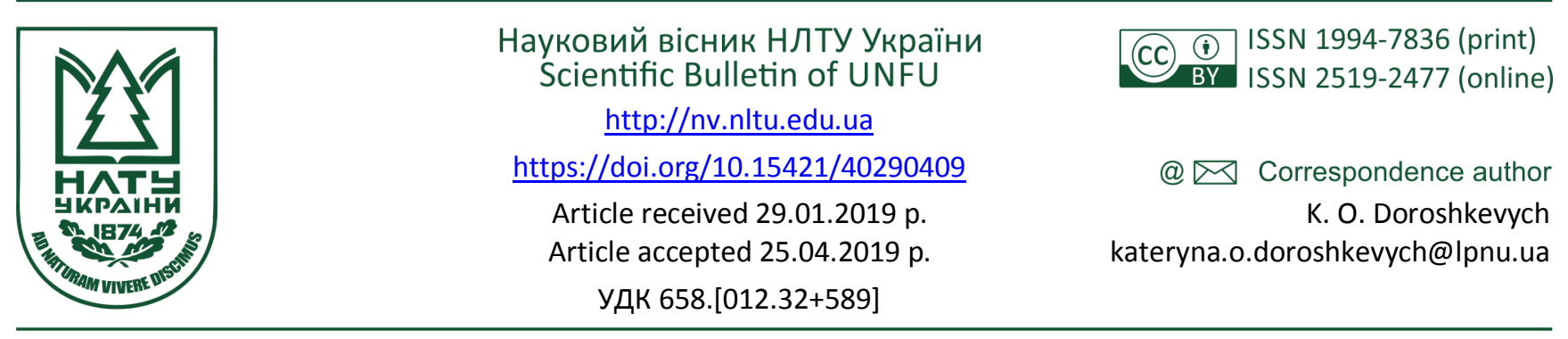

К. О. Дорошкевич1, М. М. Вороновська', І. З. Салата

${ }^{1}$ Національний університет "Львівська політехніка", м. Львів, Україна

${ }^{2}$ Національна академія сухопутних військ ім. гетьмана Петра Сагайдачного, м. Львів, Україна

\title{
ПІДХОДИ ДО ЗАБЕЗПЕЧЕННЯ МЕНТОРИНГОВОЇ ДІЯЛЬНОСТІ НА ПІДПРИЕМСТВАХ
}

Уточнено визначення та наведено основні сфери застосування менторингу (методу персоналізованого навчання та особливої системи відносин на підприємстві), які стосуються адаптації нових фахівців на робочому місці, оптимізування витрат часу на навчання і оцінювання менеджерами нових співробітників; впровадження інноваційних методів роботи на підприємстві; просування за кар'єрною ієрархією, цілеспрямованої підготовки керівників; зниження плинності кадрів тощо. Досліджено моделі менторингової діяльності підприємств: рефлексивну, "зустрічі у п'ятницю", "розкажи, покажи, зроби". Для їх результативного застосування можна використати компетентнісний, ситуаційний, системний підхід тощо. 3 метою поєднання цих підходів, створення ефективної і комплексної системи менторингової діяльності, інтегральної цілісності, що спрямована на ефективне управління підприємствами, рекомендовано процесно-структурований підхід до здійснення менторингу на підприємствах. Його складовими елементами визначено: ментора і менті як представників керуючої та керованої підсистем, процес менторингової діяльності, що спрямований на реалізацію функцій розвитку компетенцій, особистісного розвитку та розвитку відносин; порядок менторингу та його програму (містить систему стимулювання для ментора та менті; критерії обрання ментора; порядок менторингових сесій; ключові компетенції, які повинні бути набуті).

Ключові слова: мотивування; менторингова діяльність; моделі; процесно-структурований підхід.

Вступ. У нинішніх умовах господарювання, які характеризуються розвитком інноваційної діяльності, удосконаленням процесів управління підприємством, що передбачає виникнення нових методів стимулювання працівників, розвиток лідерського потенціалу, забезпечення персоналізованого навчання, генерування креативних ідей та їх втілення у діяльність підприсмства, спостерігаємо підвищений інтерес до стимулювання працівників через їх навчання і професійний та особистісний розвиток. Для цього можна застосувати менторинг, який набув поширення на багатьох вітчизняних та іноземних підприємствах, використовується у практиці діяльності консалтингових фірм, коучінгових агенцій, спеціалізованих спілок.

В економічні літературі менторинг розглядають як метод персоналізованого навчання, компететнісного наставництва, соціальної взаємодії окремих працівників та їхніх груп тощо. Його сутність можна представити як систему унікальних взаємовідносин, у якій одна людина (ментор) забезпечуе підтримку нових знань, розвитку і прогресу іншої людини (ученика, менті) (Pritcker, 2016). Проте нерідко компанії, які практикують менторинг, дають йому власне означення. Наприклад, на ПрАТ "Технопарк Санкт-Петербурга" у Тимчасовому Положенні про менторську програму, що затверджена наказом генерального директора № 054/1 від 26 червня 2012 p., зазначено, що менторинг - це тип формальних і неформальних взаємин між досвідченим працівником, який виступає в ролі наставника (ментором), і працівником, який виступає в ролі учня (протеже, менті) (Vremennoe Polozhenie o mentorskoj programme OAO "Tehnopark Sankt-Peterburga", 2012). Тому в економічній літературі та практиці діяльності консалтингових фірм можна натрапити однакові визначення поняття менторинг.

Незважаючи на використовувані сутнісні визначення поняття менторингу, сфери його застосування на підприємствах такі: адаптація нових фахівців на робочому місці, оптимізування витрат часу на навчання $\mathrm{i}$ оцінювання менеджерами нових співробітників; впровадження інноваційних методів роботи на підприємстві; просування за кар'єрною ієрархією, цілеспрямована підготовка керівників; зниження плинності кадрів, підвищення рівня лояльності працівників та їх відданості підприємству; допомога працівників, у яких відбулись зміни у трудовій діяльності, набуття менторами досвіду управління та навчання співробітників; створення сприятливого клімату в колективі, забезпечення швидкого зростання та результативності роботи працівників, спрямованості діяльності працівників на

Інформація про авторів:

Дорошкевич Катерина Олегівна, канд. екон. наук, доцент, кафедра менеджменту і міжнародного підприємництва. Email: kateryna.o.doroshkevych@lpnu.ua

Вороновська Марта Миколаївна, канд. екон. наук, ст. викладач, кафедра менеджменту і міжнародного підприємництва. Email: marta_tomych@ukr.net

Салата Ігор Зеновійович, канд. екон. наук, ст. наук. співробітник, науковий центр сухопутних військ, заступник начальника науково-дослідного відділу. Email: igor.zen9@уandex.ua

Цитування за ДСту: Дорошкевич К. О., Вороновська М. М., Салата І. З. Підходи до забезпечення менторингової діяльності на підприємствах. Науковий вісник НлтУ України. 2019, т. 29, № 4. С. 47-49.

Citation APA: Doroshkevych, K. O., Voronovska, M. M., \& Salata, I. Z. (2019). Approaches to providing mentoring activities at enterprises. Scientific Bulletin of UNFU, 29(4), 47-49. https://doi.org/10.15421/40290409 
результат; покращення комунікацій між підрозділами підприємства, покращення міжособистісної взаємодії (Pritcker, 2016; Brusenko, 2014; Morozova, 2016).

Матеріал і методи дослідження. У науковій літературі, практиці управління підприємствами та діяльності консалтингових фірм сформовано низку моделей менторингової діяльності: рефлексивна, "зустрічі у п'ятницю", "розкажи, покажи, зроби" тощо (Frolova, Bazarnova \& Goriacheva, 2017; Vasilenko \& Denisenko, 2018).

Рефлексивна модель менторингу передбачає такі етапи реалізації: навчання наставників, що охоплює розвиток компетенцій щодо здійснення менторських сесій, реалізації основних фаз наставництва, підходів до взаємодії з менті на підприємстві тощо; проектування плану розвитку ментора та створення умов для розвитку його сталої мотивації; супровід та підтримка менті, що полягає у діагностиці криз і бар'єрів у професійній сфері діяльності менті, допомогу в подоланні існуючих криз, складання плану розвитку менті; зворотний зв'язок як процес оцінювання результативності менторських сесій менторів та набутих менті знань. Модель передбачає щомісячні зустрічі менторської пари особисто або в режимі онлайн протягом двох років.

Модель "зустрічі у п'ятницю" складається із таких етапів менторингової діяльності: знайомство 3 професійними функціями менті у процесі його практичної діяльності, що здійснюється спільно 3 ментором; демонстрація ментором власного професійного стилю і лідерства 3 метою створення передумов для розвитку професійних і лідерських якостей у менті; бесіда "питання-відповідь". Модель передбачає щотижневі традиційні зустрічі менторської пари тривалістю 1,5-2 години (Frolova, Bazarnova \& Goriacheva, 2017).

Модель "розкажи, покажи, зроби" містить три етапи. На першому етапі "розкажи" наставник розповідає менті, як потрібно вчинити, чим користуватись, тобто здійснюється теоретична підготовка менті або закріплення і уточнення вже отриманих теоретичних знань. Після цього здійснюється перевірка отриманих знань. На другому етапі "покажи" наставник сам демонструє менті, як практично виконується певна робота; показує, як потрібно виконувати завдання, коментуючи свою роботу під час або після виконання, якщо немає можливості коментувати роботу у процесі ії здійснення. На третьому етапі "зроби" наставник надає можливість менті самому виконати роботу. При цьому наставник має право вимагати від менті повторно виконати всю роботу або іiі окремих елементів, якщо його не задовольняють отримані результати (Vasilenko \& Denisenko, 2018).

Не прив'язуючись до конкретної моделі, у процесі менторингу можна здійснити заходи щодо: оцінювання первинного потенціалу менті, навчання теоретичному матеріалу, практичні заняття, цілепокладання, психологічна допомога менті, стимулювання, допомога у встановленні контактів чи комунікаційній діяльності, оцінювання результатів практичної роботи, надання рекомендацій із іiі покращення тощо (Klishch \& Ianvarev, 2014).

Результати дослідження. Застосування відповідної моделі менторингової діяльності залежить від підходів до менторингу, які використовують на підприємстві. У практичній діяльності підприємств застосовується компетентнісний і ситуаційній менторинг. Перший перед- бачає прив'язку до управлінських компетенцій. Згідно 3 ним, менторинг застосовують на підприємствах не тільки 3 метою поширення знань, умінь і навичок, а для формування у працівників компетентності як загальної характеристики, що грунтується на знаннях, досвіді, цінностях, здібностях, отриманих завдяки навчанню (Hutsan, 2014).

Інший підхід до менторингу - ситуаційний - передбачає його застосування для вирішення конкретних проблем на підприємстві 3 метою досягнення цілей його діяльності. Здебільшого такі проблеми виникають ситуативно, за певного набору обставин. Його використання пов'язане $з$ тим, що управлінські компетенції розвиваються у великому колі контекстів і ситуацій. Таким чином, менторинг проводиться на основі не компетенцій, а грунтуючись на потребах розвитку організації (Klarin, 2017). Можна виділити й інші підходи до здійснення менторингу: динамічний, системний, функціональний тощо. Системний грунтується на використання теорії систем як сукупності складових елементів, які перебувають у взаємодії та взаємозв'язку. Функціональний полягає у послідовній реалізації функцій менторингової діяльності: розвитку компетенцій, особистісного розвитку, розвитку відносин (Frolova, Bazarnova $\&$ Goriacheva, 2017). Таким чином, відсутній комплексний підхід до здійснення менторингу на підприємствах. Зважаючи на це, існуючі підходи є не достатньо ефективними. Для усунення цих недоліків варто рекомендувати інтегрований підхід та виявити його складові елементи.

Обговорення отриманих результатів. 3 метою поєднання описаних підходів, створення ефективної та комплексної системи менторингової діяльності, інтегральної цілісності, що спрямована на ефективне управління підприємствами, рекомендуємо процесно-структурований підхід до здійснення менторингу на підприємствах. Процесно-структурований підхід у менеджменті рекомендував О. Є. Кузьмін. Цей підхід містить такі складові елементи: керівну та керовану підсистеми організації; функції процесно-структурованого менеджменту (загальні (планування, організування, мотивування, контролювання та регулювання), конкретні (з допомогою яких здійснюються конкретні управлінські процеси) та об'єднувальна (керівництво)); методи процесно-структурованого менеджменту; управлінські рішення; комунікації (Kuzmin, 2012).

За процесним підходом менторингова діяльність полягає у послідовній реалізації етапів менторингової діяльності, які пов'язані 3 визначенням цілей і завдань менторингу, його інформаційним забезпеченням, підбором критеріїв для менторів, укладанням програми менторингу, виявленням ключових компетенцій, реалізацією менторингових сесій, використанням системи мотиваційних заходів, набуттям бажаних компетенцій, оцінюванням результатів менторингу, закріпленням отриманих знань та їх практичним застосуванням, професійним обговоренням результатів тощо. У межах процесно-структурованого підходу, менторингова діяльність містить такі основні елементи: ментор і менті як представники керуючої та керованої підсистем підприємства; функції менторингу (розвиток компетенцій, особистісний розвиток, розвиток відносин); програма менторингу, що містить систему стимулювання для ментора та менті; критерії обрання ментора; порядок 
менторингових сесій; ключові компетенції, які повинні бути набуті у процесі менторингу тощо; порядок менторингової діяльності (рисунок).

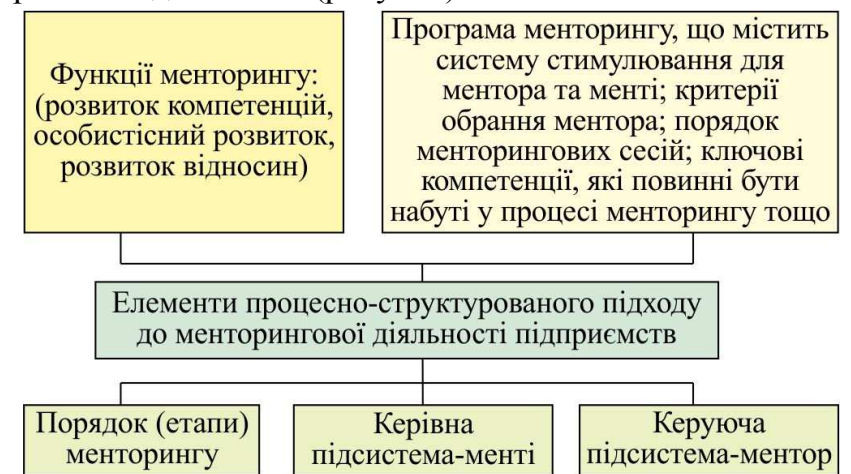

Рисунок. Основні елементи процесно-структурованого підходу до менторингової діяльності підприємств

Висновки. Менторинг - це метод персоналізованого навчання, що передбачає формування системи унікальних взаємовідносин, у якій одна людина (ментор) забезпечує підтримку нових знань, розвитку і прогресу іншої людини (ученика, менті). 3 метою забезпечення комплексного засобу реалізації менторингової діяльності та забезпечення іiї ефективності, рекомендовано системно-структурований підхід. Він грунтується на концепції, згідно з якою менторингову діяльність розглядають як процес, що є послідовністю певних завершених етапів (інформаційне забезпечення, виявлення ключових компетенцій, реалізація менторингових сесій, використання системи мотиваційних заходів, набуття бажаних компетенцій, оцінювання результатів менторингу). У своїй сукупності ці етапи забезпечують розвиток ключових компетенцій працівників 3 метою досягнення цілей організації у відповідних умовах функціонування чи за певних обставин. Ключовими елементами процесно-структурованого підходу є: ментор і менті як представники керуючої та керованої підсистем, процес менторингової діяльності, що спрямований на реалізацію функцій розвитку компетенцій, особистісного розвитку та розвитку відносин; порядок менторингу та його програма.
У подальших дослідженнях за проблемою потрібно дослідити концептуальні засади менторингової діяльності підприємств в умовах інноваційного розвитку.

\section{Перелік використаних джерел}

Brusenko, N. V. (2014). Rozrobka prohramy mentorynhu na pidpryiemstvi: osnovni skladovi. (Ser. Ekonomichni nauky). Visnyk Chernivetskoho torhovelno-ekonomichnoho instytutu, 1, 195-202. Retrieved from: http://nbuv.gov.ua/UJRN/Vchtei 2014127 . [In Ukrainian].

Frolova, S. V., Bazarnova, N. D., \& Goriacheva, N. A. (2017). Korporativnyi mentoring kak instrument professionalnogo rosta molodogo spetcialista. Gosudarstvennyi Sovetnik, 4, 45-49. [In Ukrainian].

Hutsan, L. A. (2014). Kompetentnisno spriamovana osvita - suchasnyi oriientyr navchalno-vykhovnoho protsesu. Naukovi zapysky NDU im. M. Hoholia. Psykholoho-pedahohichni nauky, 2, 68-72. [In Ukrainian].

Klarin, M. V. (2017). Korporativnyi trening, nastavnichestvo, kouching. Moscow: Yurait, 288 r. [In Russian].

Klishch, N. N., \& Yanvarev, V. A. (2014). Nastavnichestvo na gosudarstvennoi sluzhbe - novaia tekhnologiia professionalnogo razvitiia gosudarstvennykh sluzhashchikh (zarubezhnyi i rossiiskii opyt nastavnichestva na gosudarstvennoi sluzhbe). Moscow: Vysshaya shkola ekonomiki, 64 r. [In Russian].

Kuzmin, O. Ye. (2012). Kontseptsiia ta evoliutsiia protsesno-strukturovanoho menedzhmentu. Ekonomika: realii chasu, 2(3), 7-16. Retrieved from: https:/economics.opu.ua/files/archive/2012/No2/716.pdf. [In Ukrainian].

Morozova, M. E. (2016). Nastavnytstvo yak protses formuvannia osobystosti molodoho spetsialista. Ekonomika ta upravlinnia: istoriia, realii ta perspektyvy, 1. Retrieved from: http:/umo.edu.ua/images/content/institutes/imp/vydannya/visnyk u mo/ekonomika/MOPO3OBA.pdf. [In Ukrainian].

Pritcker, A. I. (2016). Puteshestvie v mentoring, 144 r. [In Russian].

Tehnopark. (2012). Vremennoe Polozhenie o mentorskoj programme OAO "Tehnopark Sankt-Peterburga". Utverzhdeno prikazom generalnogo direktora, 054/1 ot 26 ijunja 2012. [In Russian].

Vasilenko, G. N., \& Denisenko, E. S. (2018). Individualnoe obuchenie i razvitiia instituta nastavnichestva $\mathrm{v}$ organakh vnutrenikh del. Vestnik Moskovskogo universiteta MVD Rossii, 2, 139-144. Retrieved from: https://cyberleninka.ru/article/n/individualnoeobuchenie-i-perspektivy-razvitiya-instituta-nastavnichestva-vorganah-vnutrennih-del. [In Russian].

K. O. Doroshkevych', M. M. Voronovska', I. Z. Salata ${ }^{2}$

${ }^{I}$ Lviv Polytechnic National University, Lviv, Ukraine

${ }^{2}$ Hetman Petro Sahaidachnyi National Army Academy, Lviv, Ukraine

\section{APPROACHES TO PROVIDING MENTORING ACTIVITIES AT ENTERPRISES}

The article clarifies the definition and defines the main areas of the use of mentoring (a method of personalized learning and a special system of unique relationships in which one person (mentor) provides support for new knowledge, development and progress of another person (student, mentee)) that relate to the adaptation of new professionals to workplace, optimization of time spent on training and evaluation by managers of new employees; introduction of innovative methods of work at the enterprise; advancement in career hierarchy, purposeful training of managers; reduction of staff turnover, increase of employees loyalty and their commitment to the enterprise; creation of a favourable climate in the team etc. The models of mentoring activity of enterprises are investigated: reflexive, "meetings on Friday", "tell, show, do". For their efficient application we can use competent, situational, systemic, and dynamic approaches. In order to combine these approaches, and to create an effective and integrated system of mentoring activities, integral integrity, aimed at effective management of enterprises, we recommend a process-structured approach to the implementation of mentoring on enterprise. Its constituent elements are defined as follows: mentors and mentee as representatives of control and controlled subsystems; the process of mentoring activity aimed at the implementation of functions of development of competences; personal development and development of relations on enterprise; the procedure for mentoring (information provision, the identification of key competencies, the implementation of mentoring sessions, the use of a system of motivational measures, the acquisition of desirable competencies, the evaluation of the results of mentoring) and its program (contains a system of motivation for mentor and mentee, criteria for choosing a mentor, the procedure of mentoring sessions, key competencies, which should be acquired).

Keywords: motivation; mentoring activity; models; process-structured approach. 